\title{
The Garden Candytuft (Iberis umbellata L.): At the Crossroad of Copper Accumulation and Glucosinolates
}

\author{
Mario Nikola Mužek 1,*(D), Dario Omanović ${ }^{2} \mathbb{D}$, Azra $^{\text {Dulović }}{ }^{3}\left(\mathbb{D}\right.$, Franko Burčul ${ }^{4}(\mathbb{D}$, \\ Sandra Svilović ${ }^{5}$ (D) and Ivica Blažević ${ }^{3}$ (D) \\ 1 Department of Inorganic Technology, Faculty of Chemistry and Technology, University of Split, \\ Ruđera Boškovića 35, 21000 Split, Croatia \\ 2 Division for Marine and Environmental Research, Laboratory for physical chemistry of traces, \\ Ruđer Bošković Institute, Bijenička cesta 54, 10000 Zagreb, Croatia; omanovic@irb.hr \\ 3 Department of Organic Chemistry, Faculty of Chemistry and Technology, University of Split, \\ Ruđera Boškovića 35, 21000 Split, Croatia; azra@ktf-split.hr (A.Đ.); blazevic@ktf-split.hr (I.B.) \\ 4 Department of Analytical Chemistry, Faculty of Chemistry and Technology, University of Split, \\ Ruđera Boškovića 35, 21000 Split, Croatia; franko@ktf-split.hr \\ 5 Department of Chemical Engineering, Faculty of Chemistry and Technology, University of Split, \\ Ruđera Boškovića 35, 21000 Split, Croatia; sandra@ktf-split.hr \\ * Correspondence: muky@ktf-split.hr
}

Received: 31 July 2020; Accepted: 4 September 2020; Published: 8 September 2020

\begin{abstract}
The copper accumulation ability and its impact on the glucosinolate content of the garden candytuft were studied. Different copper sources (adsorbents or solution) were used. Generally, the seedlings copper uptake from the adsorbents was in the amount needed for its growth and development with the beneficial or no impact on the glucosinolate content. The lowest copper concentration was detected in the total seedlings biomass which grew in the humus with the addition of Cu-exchanged zeolite $\mathrm{NaX}\left(27.88 \mu \mathrm{g} \mathrm{g}^{-1} \mathrm{DW}\right)$ having glucosinolate content of $9757.81 \mu \mathrm{g} \mathrm{g}^{-1} \mathrm{DW}$ $\left(23.86 \mu \mathrm{mol} \mathrm{g}^{-1} \mathrm{DW}\right)$. The highest copper concentration among all the garden candytuft samples was detected in the seedlings watered with $\mathrm{CuSO}_{4} \cdot 5 \mathrm{H}_{2} \mathrm{O}$ solution $\left(514.63 \mu \mathrm{g} \mathrm{g}^{-1} \mathrm{DW}\right)$ with a sharp decrease of the glucosinolate content $3103.33 \mu \mathrm{g} \mathrm{g}^{-1} \mathrm{DW}\left(7.59 \mu \mathrm{mol} \mathrm{g}^{-1} \mathrm{DW}\right)$. Based on the results obtained, the garden candytuft can be considered as a copper accumulator plant.
\end{abstract}

Keywords: garden candytuft; Iberis umbellata L.; copper; glucosinolates; accumulation

\section{Introduction}

The term heavy metal is assigned to the transition metals with specific gravity above $5 \mathrm{~g} \mathrm{~cm}^{-3}$ and atomic mass over 20. Heavy metals are elements that naturally occur in soils. Due to the pollution from anthropogenic sources their amount can easily be increased. It refers to a series of metals, and also metalloids that can be toxic to all living beings even at very low concentrations. Some of these heavy metals $(\mathrm{As}, \mathrm{Cd}, \mathrm{Hg}$, or $\mathrm{Pb}$ ) do not perform any known physiological function in plants and therefore they are not essential elements, while others are essential elements $(\mathrm{Co}, \mathrm{Cu}, \mathrm{Fe}, \mathrm{Mn}, \mathrm{Mo}, \mathrm{Ni}$, and $\mathrm{Zn})$ required for normal growth and development of plant. Essential elements can also become toxic when found in large concentrations in plants [1-3].

Copper is one of the essential micronutrients needed for plant growth and development. It has a role in numerous physiological functions such as respiration, photosynthesis, $\mathrm{C}$ and $\mathrm{N}$ metabolism, and oxidative stress protection in the range of physiological concentration $\left(1-30 \mu \mathrm{g} \mathrm{g}^{-1}\right)$ [4]. Copper ranks as the third-most-consumed industrial metal in the world (after Fe and Al). Elementary 
copper occurs naturally, but its greatest sources are, by far, minerals such as chalcopyrite and bornite. A discharge of large amounts of metal-contaminated wastewaters in the environment causes a serious problem in the scope of environmental protection and, entering the food chain, they can be absorbed by all living organisms causing serious health disorders [5]. There are an innumerable number of studies on how to remove heavy metals from wastewater, and the most investigated ones are by using adsorption on various adsorbents [6-15]. The question arises what to do with the adsorbents after heavy metal adsorption, because not all of them can be used for a long period of time or for other purposes.

Some plants are known to possess metal hyperaccumulation ability, i.e., to tolerate, actively take up large amounts of heavy metals from the soil by the roots, translocate them to the shoot, and store unusually high amounts of metal or metalloid in aboveground organs, especially leaves, at concentrations much higher than those found in non-hyperaccumulating species, without showing symptoms of phytotoxicity [3,16-19]. Plants with elevated but not extraordinary levels of heavy metals in plant tissues are known as metal indicators or accumulator plants. The numbers of accumulator plant species are poorly known, because the boundaries between these two categories are arbitrary and most of the studies are focused on finding the hyperaccumulators [20,21]. Accumulator or hyperaccumulator ability can be used to remove harmful elements from used adsorbent disposed in the soil where these plants are being cultivated.

There are a lot of angiosperm species identified so far as heavy metal ( $\mathrm{As}, \mathrm{Cd}, \mathrm{Co}, \mathrm{Cu}, \mathrm{Mn}, \mathrm{Ni}, \mathrm{Pb}$, $\mathrm{Sb}, \mathrm{Se}, \mathrm{Tl}, \mathrm{Zn}$ ) hyperaccumulators (ca. 450) [2]. Many of these metal hyperaccumulators are members of the Brassicaceae family [22]. This family is, without exception, strikingly chemocharacterized by the presence of thiosaccharidic secondary metabolites-glucosinolates [23]. These compounds were suggested to have roles in their metal tolerance mechanisms [24].

The goals of this work were to test growing ability of garden candytuft on the humus mixed with various adsorbents on which the copper, as heavy metal was previously adsorbed; follow the growth and development of the garden candytuft; test the copper accumulation ability of the garden candytuft and its response to the induced abiotic stress by the glucosinolate content analysis.

\section{Materials and Methods}

\subsection{Materials and Reagents}

Seeds of Iberis umbelata L. were obtained commercially (Tuinplus b. v. Heerenveen, The Netherlands). Copper sulphate pentahydrate $\left(\mathrm{CuSO}_{4} \cdot 5 \mathrm{H}_{2} \mathrm{O}\right)$ was obtained from Kemika, p.a; humus (COMPO SANA) was manufactured by Compo $\mathrm{GmbH}$ (Münster, Germany). According to the specification found on the package humus is declared as a soil for sowing and medicinal plants. It is a high-value special soil for growing all kinds of plants in pots and gardens. The composition is also suitable for growing medicinal plants with $\mathrm{pH}$ value $\left(\mathrm{CaCl}_{2}\right)$ : 5.0-6.5, salt content $\left(\mathrm{g} \mathrm{dm}^{-3}\right)$ : 1.0-1.5, nutrient content: 50-250 N, 80-300 $\mathrm{P}_{2} \mathrm{O}_{5}, 100-350 \mathrm{~K}_{2} \mathrm{O}$. It consists of raw materials such as high-value peat $\left(\mathrm{H}_{5}-\mathrm{H}_{7}\right)(96 \%)$, green compost (4\%), Agrosil, real COMPO Guano, lime and nutrients. Zeolite NaX, DEAE-Sephadex A-25 anion-exchange resin, sulfatase (type $\mathrm{H}-1$ from Helix pomatia), sinigrin, and certified reference material of known glucosinolate composition (ERM-BC367) were obtained from Sigma Aldrich (Merck KgaA, St. Louis, MO, USA), while gluconapin, glucotropaeolin and 4-methoxyglucobrassicin were obtained from Phytoplan (Phytoplan Diehm \& Neuberger GmbH, Heidelberg, Germany). All other chemicals and reagents were of analytical grade.

\subsection{Preparation of Adsorbents and Adsorption Studies}

Zeolite NaX, egg shells (crushed) and humus were used as an adsorbent material in this study. Zeolite $\mathrm{NaX}$ used was composed of particles whose size was smaller than $45 \mu \mathrm{m}$. Egg shell particles size was less than $125 \mu \mathrm{m}$, and humus particles were smaller than $500 \mu \mathrm{m}$. 
The initial concentration of solution containing copper ions $\left(7.95 \mathrm{mmol} \mathrm{dm}^{-3}\right)$ was prepared by dissolving $\mathrm{CuSO}_{4} \cdot 5 \mathrm{H}_{2} \mathrm{O}$ in distilled water. The initial concentration, as well as concentration of solutions after adsorption process were checked by UV/Vis spectrophotometer (Lambda EZ201, Perkin Elmer, Waltham, MA, USA) at wavelength of $810 \mathrm{~nm}$ using an absorbance-concentration calibration curve $\operatorname{abs}(\mathrm{c})=1.025 \cdot 10^{-4}+0.0118 \cdot \mathrm{c}$ having correlation coefficient 0.9999 . Calibration curve was obtained by measuring absorbance of previously prepared solutions with known copper concentrations in the range from 0.60 to $21 \mathrm{mmol} \mathrm{dm}^{-3}$.

Adsorption of the $\mathrm{Cu}$ ions on various adsorbents was carried out in the batch reactors at room temperature for all the adsorbents used. The suspensions were prepared by mixing $10 \mathrm{~g}$ of adsorbent with $0.5 \mathrm{dm}^{3}$ of $\mathrm{CuSO}_{4} \cdot 5 \mathrm{H}_{2} \mathrm{O}$ solution in each batch reactor. The suspensions were kept in a thermostatic orbital shaker (200 rpm) for 10 days in order to achieve the maximum adsorption. After 10 days of mixing the suspensions were filtered through filter paper Whatman 42. Obtained filtered copper solutions were used for measuring the $\mathrm{Cu}$ ions concentration remained in the solutions by UV/Vis spectrophotometer. The amount of the copper retained on the adsorbent, $q_{10}$, was calculated according to the Equation (1) and reported in Table 1:

$$
q_{10}=\left[\left(c_{0}-c_{10}\right) V\right] / m
$$

where $c_{10}$ is concentration of $\mathrm{Cu}$ in the solution after 10 days $\left(\mathrm{mmol} \mathrm{dm}^{-3}\right), c_{0}$ is the initial concentration of $\mathrm{Cu}$ in the solution $\left(\mathrm{mmol} \mathrm{dm}{ }^{-3}\right), V$ is the volume of solution $\left(\mathrm{dm}^{3}\right)$, and $m$ is the mass of adsorbent $(\mathrm{g})$.

Table 1. Experimental data obtained after 10 days of adsorption process.

\begin{tabular}{lccc}
\hline Adsorbent/Concentration & Zeolite NaX & Egg shells & Humus \\
\hline$c_{0}\left(\mathrm{mmol} \mathrm{dm}^{-3}\right)$ & 0.38 & 7.95 \\
$c_{10}\left(\mathrm{mmol} \mathrm{dm}^{-3}\right)$ & 0.38 & 0.13 & 3.99 \\
$q_{10}\left(\mathrm{mmol} \mathrm{g}^{-1}\right)$ & 24.02 & 0.39 & 0.20 \\
$q_{10}\left(\mathrm{mg} \mathrm{g}^{-1}\right)$ & 95.22 & 24.85 & 12.52 \\
Adsorption efficiency $(\%)$ & 98.36 & 49.81 \\
\hline
\end{tabular}

$c_{0}$ is the initial concentration of $\mathrm{Cu}$ in the solution $\left(\mathrm{mmol} \mathrm{dm}^{-3}\right) ; c_{10}$ is concentration of $\mathrm{Cu}$ in the solution after 10 days $\left(\mathrm{mmol} \mathrm{dm}^{-3}\right) ; q_{10}$ is the amount of the copper retained on the adsorbent $\left(\mathrm{mmol} \mathrm{g}^{-1}\right)$.

\subsection{Metal Accumulation Studies}

After adsorption and filtration each adsorbent was mixed with $35 \mathrm{~g}$ of humus. The adsorbent addition changed the original $\mathrm{pH}$ value of humus $(\mathrm{pH}=5.62)$ depending on the adsorbent added, as follows: humus with zeolite $\mathrm{NaX}$ addition $(\mathrm{pH}=6.59)$; humus with extra humus addition $(\mathrm{pH}=5.34)$; humus with egg shells addition $(\mathrm{pH}=6.54)$.

The seeds of the garden candytuft were planted in flowerpots with the prepared soils and germination, growth, and development were monitored. The garden candytuft planted in humus mixed with added adsorbents, was exclusively watered with a tap water. Additionally, a garden candytuft was planted in untreated humus and watered with $590 \mathrm{~cm}^{3}$ of $\mathrm{CuSO}_{4} \cdot 5 \mathrm{H}_{2} \mathrm{O}$ solution. Finally, the garden candytuft was planted also in untreated humus and watered only with tap water, which served as a control sample. The samples were watered with tap water or the copper solution when needed.

\section{Metal Analysis}

After forty days of cultivation, the garden candytuft from each flowerpot was harvested and left to dry at room temperature (ca. $25^{\circ} \mathrm{C}$ ) over a period of two days and afterwards in the laboratory dryer oven at $75^{\circ} \mathrm{C}$ to constant mass, in order to obtain the dry weight.

Porcelain crucibles were filled with $1 \mathrm{~g}$ of dried, pulverized seedling sample, placed in a cool muffle furnace and ashed at $500{ }^{\circ} \mathrm{C}$ overnight. Afterwards, the ashes were cooled and dissolved 
in $5 \mathrm{~cm}^{3}$ of $20 \% \mathrm{HCl}$ and the solutions obtained were filtered through an acid-washed filter paper (Whatman 42) into a $50 \mathrm{~cm}^{3}$ volumetric flask. The filter papers were washed with deionized water and the solutions were diluted to the volume with deionized water as well and mixed thoroughly.

The heavy metal concentrations in the prepared solutions were determined by Element 2, High Resolution Inductively Coupled Plasma Mass Spectrometer (HR ICPMS, Thermo Finnigan, Bremen, Germany). The samples for the analyses were prepared in pre-cleaned polyethylene tubes by adding $100 \mu \mathrm{L}$ of concentrated $\mathrm{HNO}_{3}$ and $50 \mu \mathrm{L}$ of indium (115) internal standard $\left(0.1 \mathrm{mg} \mathrm{dm}^{-3}\right)$ into $5 \mathrm{~cm}^{3}$ of a sample aliquot.

The concentrations of the metals were determined by means of external calibration plots. No special setup of the instrument operating conditions was needed. Quality control (QC) of HR ICP-MS measurements was checked by the determination of elements concentration in "River Water Reference Material for Trace Metals" (SLRS-5, National Research Council Canada). For most elements, a good agreement with the certified data was obtained.

\subsection{Glucosinolates Analysis}

Glucosinolates were determined by their desulfo-counter parts and analysed by UHPLC-DAD-MS/MS.

\subsubsection{Isolation of Desufoglucosinolates}

Isolation of desulfoglucosinolates (dGSLs) from $100 \mathrm{mg}$ of dried seedling material was performed, as previously reported [25]. Seedling material was firstly subjected to extraction in $\mathrm{MetOH} / \mathrm{H}_{2} \mathrm{O}$ (70:30 $v / v)$. The supernatant was loaded on to a mini-column filled with DEAE-Sephadex A-25 anion-exchange resin and the columns were then washed to remove the remaining non-polar compounds. To create optimal conditions for the sulfatase reaction, mini columns were then washed with $20 \mathrm{mM} \mathrm{NaOAc}$ buffer followed by addition of enzyme sulfatase. The reaction was left overnight and the dGSLs were eluted the next day with the ultrapure $\mathrm{H}_{2} \mathrm{O}$.

\subsubsection{UHPLC-DAD-MS/MS Analysis of Desulfoglucosinolates}

Analysis was performed by UHPLC-DAD-MS/MS (Ultimate 3000RS equipped with DAD and TSQ Quantis MS/MS detectors, Thermo Fischer Scientific, Waltham, MA, USA) using Hypersil GOLD column $(3.0 \mu \mathrm{m}, 3.0 \times 100 \mathrm{~mm}$, Thermo Fischer Scientific, Waltham, MA, USA). A gradient consisting of solvent $\mathrm{A}\left(50 \mu \mathrm{M} \mathrm{NaCl}\right.$ in $\mathrm{H}_{2} \mathrm{O}$ ) and solvent $\mathrm{B}$ (acetonitrile: $\mathrm{H}_{2} \mathrm{O} 30: 70 v / v$ ) was applied at a flow rate of $0.5 \mathrm{~mL} \mathrm{~min}^{-1}$ as follows: $0.14 \mathrm{~min} 96 \% \mathrm{~A}$ and $4 \% \mathrm{~B} ; 7.84 \mathrm{~min} 14 \% \mathrm{~A}$ and $86 \% \mathrm{~B} ; 8.96 \mathrm{~min}$ $14 \% \mathrm{~A}$ and $86 \% \mathrm{~B} ; 9.52 \mathrm{~min} 5 \% \mathrm{~A}$ and $95 \% \mathrm{~B} ; 13.16 \mathrm{~min} 5 \% \mathrm{~A}$ and $95 \% \mathrm{~B} ; 13.44 \mathrm{~min} 96 \% \mathrm{~A}$ and $4 \% \mathrm{~B}$; $15.68 \mathrm{~min} 96 \% \mathrm{~A}$ and $4 \% \mathrm{~B}$. The column temperature was held at $25{ }^{\circ} \mathrm{C}$ and the injection volume was $5 \mu \mathrm{L}$. The system was operated in the positive ion electrospray mode and the electrospray interface was $\mathrm{H}$-ESI, operating with a capillary voltage of $3.5 \mathrm{kV}$ at $350^{\circ} \mathrm{C}$. The signals were recorded at the $227 \mathrm{~nm}$ by DAD detector. Quantification of dGSLs was performed using an external calibration curve of pure desulfosinigrin (range from 13.56 to $542.50 \mu \mathrm{M}$ ). For each individual dGSL response factors (RPF) was taken in accordance to the literature: RPF 0.80 for glucoibervirin (4) [26], 1.07 for glucoiberin (1), 1.00 for sinigrin (2), 1.11 for gluconapin (3), 0.95 for glucotropaeolin (5), 0.25 for 4-methoxyglucobrassicin (6) [27].

\subsection{Statistical Analysis}

Analysis of variance (one-way ANOVA) was used to assess the statistical difference between data reported in Table 2, followed by a least significance difference test to evaluate differences between sets of mean values at significance level set at $p<0.05$. Analyses were carried out using Statgraphics Centurion-Ver.16.1.11 (StatPoint Technologies, Inc., Warrenton, VA, MA, USA) [28]. 
Table 2. Measured heavy metals concentration in the garden candytuft seeds, and the cultivated garden candytuft (total seedlings biomass), respectively.

\begin{tabular}{|c|c|c|c|c|c|c|c|c|c|c|c|c|c|c|c|}
\hline \multirow[t]{2}{*}{ Samples } & \multicolumn{9}{|c|}{$\begin{array}{l}\text { Heavy Metal } \\
\left(\mu \mathrm{g} \mathrm{g}^{-1} \mathrm{DW}\right)\end{array}$} & \multicolumn{6}{|c|}{$\begin{array}{l}\text { Glucosinolates * } \\
\left(\mu \mathrm{g} \mathrm{g}^{-1} \mathrm{DW}\right)\end{array}$} \\
\hline & $\mathrm{Cu}$ & $\mathrm{Cd}$ & $\mathrm{Pb}$ & Mo & Mn & $\mathrm{Fe}$ & Co & $\mathrm{Ni}$ & $\mathrm{Zn}$ & 1 & 2 & 3 & 4 & 5 & 6 \\
\hline Humus Compo Sana & $\begin{array}{c}10.19 \pm \\
0.02^{\mathrm{a}}\end{array}$ & $\begin{array}{l}0.05 \pm \\
0.00^{\mathrm{a}}\end{array}$ & $\begin{array}{l}1.71 \pm \\
0.00^{a}\end{array}$ & $\begin{array}{l}0.01 \pm \\
0.00^{\mathrm{a}}\end{array}$ & $\begin{array}{c}19.29 \pm \\
0.04^{\mathrm{a}}\end{array}$ & $\begin{array}{c}263.31 \pm \\
0.85^{\mathrm{a}}\end{array}$ & $\begin{array}{l}0.13 \pm \\
0.00^{\mathrm{a}}\end{array}$ & $\begin{array}{l}0.92 \pm \\
0.00^{\mathrm{a}}\end{array}$ & $\begin{array}{c}15.41 \pm \\
0.02^{\mathrm{a}}\end{array}$ & l & l & 1 & 1 & l & l \\
\hline $\begin{array}{l}\text { The garden } \\
\text { candytuft seeds }\end{array}$ & $\begin{array}{l}3.53 \pm \\
0.08^{a}\end{array}$ & $\begin{array}{l}0.07 \pm \\
0.00^{\mathrm{b}}\end{array}$ & $\begin{array}{l}0.34 \pm \\
0.00^{\mathrm{b}}\end{array}$ & $\begin{array}{l}0.74 \pm \\
0.01^{\mathrm{b}}\end{array}$ & $\begin{array}{l}9.88 \pm \\
0.19^{b}\end{array}$ & $\begin{array}{l}53.66 \pm \\
0.02^{\mathrm{b}}\end{array}$ & $\begin{array}{l}0.01 \pm \\
0.00^{\mathrm{b}}\end{array}$ & $\begin{array}{l}1.33 \pm \\
0.04^{\mathrm{b}}\end{array}$ & $\begin{array}{c}33.88 \pm \\
0.36^{\mathrm{b}}\end{array}$ & $\begin{array}{l}3155.08 \pm \\
169.68 \text { ac }\end{array}$ & $\begin{array}{c}23434.24 \pm \\
1124.09^{\mathrm{a}}\end{array}$ & $\begin{array}{c}41.07 \pm \\
4.51\end{array}$ & $\begin{array}{c}2131.23 \pm \\
136.98^{\mathrm{a}}\end{array}$ & $\begin{array}{c}290.69 \pm \\
10.41^{\mathrm{a}}\end{array}$ & $\operatorname{tr}$ \\
\hline $\begin{array}{c}\text { The control } \\
\text { seedling sample }\end{array}$ & $\begin{array}{l}4.31 \pm \\
0.07^{\mathrm{a}}\end{array}$ & $\begin{array}{l}0.23 \pm \\
0.01^{\mathrm{c}}\end{array}$ & $\begin{array}{l}2.90 \pm \\
0.02^{\mathrm{c}}\end{array}$ & $\begin{array}{l}0.44 \pm \\
0.03^{c}\end{array}$ & $\begin{array}{c}171.06 \pm \\
4.41^{\mathrm{c}}\end{array}$ & $\begin{array}{l}24.27 \pm \\
0.28 \mathrm{~cd}\end{array}$ & $\begin{array}{l}0.03 \pm \\
0.00^{c}\end{array}$ & $\begin{array}{l}1.42 \pm \\
0.03^{c}\end{array}$ & $\begin{array}{c}140.56 \pm \\
3.46^{\mathrm{c}}\end{array}$ & $\begin{array}{c}1956.57 \pm \\
71.23^{\mathrm{b}}\end{array}$ & $\begin{array}{l}4785.42 \pm \\
395.24 \text { bd }\end{array}$ & n.d. & $\begin{array}{c}1079.88 \pm \\
57.49^{\mathrm{b}}\end{array}$ & $\begin{array}{c}16.38 \pm \\
2.54^{\mathrm{b}}\end{array}$ & $\begin{array}{c}14.36 \pm \\
0.00^{\mathrm{a}}\end{array}$ \\
\hline $\begin{array}{c}\text { Seedlings grown in } \\
\text { humus with zeolite } \mathrm{NaX} \\
\text { addition watered only } \\
\text { with } \mathrm{H}_{2} \mathrm{O}\end{array}$ & $\begin{array}{l}27.88^{ \pm} \\
0.73^{\mathrm{b}}\end{array}$ & $\begin{array}{l}0.06 \pm \\
0.00 \mathrm{ab}\end{array}$ & $\begin{array}{l}0.30 \pm \\
0.00^{\mathrm{b}}\end{array}$ & $\begin{array}{l}0.17 \pm \\
0.01\end{array}$ & $\begin{array}{l}57.14 \pm \\
1.85^{\mathrm{d}}\end{array}$ & $\begin{array}{l}22.87 \pm \\
1.00^{\mathrm{cd}}\end{array}$ & $\begin{array}{l}0.03 \pm \\
0.00^{c}\end{array}$ & $\begin{array}{l}1.03 \pm \\
0.03^{\mathrm{d}}\end{array}$ & $\begin{array}{l}107.87 \pm \\
1.93^{\mathrm{d}}\end{array}$ & $\begin{array}{l}3138.14 \pm \\
334.66^{\mathrm{ac}}\end{array}$ & $\begin{array}{c}4538.99 \pm \\
414.89^{\mathrm{b}}\end{array}$ & n.d. & $\begin{array}{c}1784.85^{ \pm} \\
173.79^{\mathrm{c}}\end{array}$ & $\begin{array}{l}90.07^{ \pm} \\
20.89^{\mathrm{c}}\end{array}$ & $\begin{array}{l}205.76 \pm \\
6.72^{\mathrm{b}}\end{array}$ \\
\hline $\begin{array}{c}\text { Seedlings grown in } \\
\text { humus with extra humus } \\
\text { addition watered only } \\
\text { with } \mathrm{H}_{2} \mathrm{O}\end{array}$ & $\begin{array}{l}39.82 \pm \\
0.59^{c}\end{array}$ & $\begin{array}{l}0.09 \pm \\
0.01\end{array}$ & $\begin{array}{l}0.92 \pm \\
0.02^{\mathrm{d}}\end{array}$ & $\begin{array}{l}0.46 \pm \\
0.01^{\mathrm{c}}\end{array}$ & $\begin{array}{l}60.33 \pm \\
1.02^{\mathrm{d}}\end{array}$ & $\begin{array}{l}18.61 \pm \\
0.59^{c}\end{array}$ & $\begin{array}{l}0.03 \pm \\
0.00^{c}\end{array}$ & $\begin{array}{l}1.44 \pm \\
0.03^{c}\end{array}$ & $\begin{array}{l}108.86 \pm \\
1.24^{\mathrm{d}}\end{array}$ & $\begin{array}{c}3443.60 \pm \\
494.73^{\mathrm{a}}\end{array}$ & $\begin{array}{c}2313.22^{ \pm} \\
196.61^{\mathrm{c}}\end{array}$ & n.d. & $\begin{array}{l}1426.25 \pm \\
129.83^{\mathrm{d}}\end{array}$ & $\begin{array}{l}16.38 \pm \\
3.12^{\mathrm{b}}\end{array}$ & $\begin{array}{l}334.95 \pm \\
23.25^{\mathrm{c}}\end{array}$ \\
\hline $\begin{array}{c}\text { Seedlings grown in } \\
\text { humus with egg shell } \\
\text { addition watered only } \\
\text { with } \mathrm{H}_{2} \mathrm{O}\end{array}$ & $\begin{array}{l}44.45^{ \pm} \\
3.05^{c}\end{array}$ & $\begin{array}{l}0.03 \pm \\
0.0 e^{\mathrm{e}}\end{array}$ & $\begin{array}{l}2.12 \pm \\
0.09^{\mathrm{e}}\end{array}$ & $\begin{array}{l}0.18 \pm \\
0.00^{d}\end{array}$ & $\begin{array}{l}27.96 \pm \\
0.44 \mathrm{e}\end{array}$ & $\begin{array}{l}27.35 \pm \\
0.18^{\mathrm{cd}}\end{array}$ & $\begin{array}{l}0.02 \pm \\
0.00^{d}\end{array}$ & $\begin{array}{l}1.05 \pm \\
0.01 \mathrm{~d}\end{array}$ & $\begin{array}{l}69.10 \pm \\
2.65^{\mathrm{e}}\end{array}$ & $\begin{array}{c}2769.69 \pm \\
295.50^{\mathrm{c}}\end{array}$ & $\begin{array}{c}5647.91 \pm \\
493.25^{\mathrm{d}}\end{array}$ & n.d. & $\begin{array}{c}888.35 \pm \\
97.19 \mathrm{e}\end{array}$ & $\begin{array}{l}32.75 \pm \\
5.63^{d}\end{array}$ & $\begin{array}{l}110.06 \pm \\
1.56^{\mathrm{d}}\end{array}$ \\
\hline $\begin{array}{l}\text { Seedlings grown in pure } \\
\text { humus and watered only } \\
\text { with } \mathrm{CuSO}_{4} \cdot 5 \mathrm{H}_{2} \mathrm{O}\end{array}$ & $\begin{array}{l}514.63 \pm \\
9.97^{\mathrm{d}}\end{array}$ & $\begin{array}{l}0.29 \pm \\
0.01^{f}\end{array}$ & $\begin{array}{l}0.67 \pm \\
0.01^{\mathrm{f}}\end{array}$ & $\begin{array}{l}0.39 \pm \\
0.03^{\mathrm{e}}\end{array}$ & $\begin{array}{c}129.82 \pm \\
5.31^{\mathrm{f}}\end{array}$ & $\begin{array}{l}29.86 \pm \\
1.22^{d}\end{array}$ & $\begin{array}{l}0.07 \pm \\
0.00 \mathrm{e}\end{array}$ & $\begin{array}{l}2.26 \pm \\
0.09^{\mathrm{e}}\end{array}$ & $\begin{array}{l}41.28 \pm \\
1.77^{\mathrm{f}}\end{array}$ & $\begin{array}{c}1264.15 \pm \\
52.94^{\mathrm{d}}\end{array}$ & $\begin{array}{c}1776.65 \pm \\
172.34^{\mathrm{c}}\end{array}$ & n.d. & $\begin{array}{r}12.28 \pm \\
0.00^{\mathrm{f}}\end{array}$ & $\operatorname{tr}$ & $\begin{array}{c}50.25 \pm \\
0.55^{\mathrm{e}}\end{array}$ \\
\hline
\end{tabular}

n.d.-not detected; $\operatorname{tr}<0.1 \mu \mathrm{mol} \mathrm{g}{ }^{-1} \mathrm{DW}$; DW—dried weight; * Glucosinolates identified: (1) Glucoiberin; (2) Sinigrin; (3) Gluconapin; (4) Glucoibervirin; (5) Glucotropaeolin; (6) 4-Methoxyglucobrassicin. Chromatograms and $\mathrm{MS}^{2}$ spectra were given on Figures S1 and S2. Results are presented as mean \pm SD $(n=3)$. ${ }^{\mathrm{a}-\mathrm{f}}$ Different letters in the same column denote statistically significant difference $(p<0.05)$ between samples. 


\section{Results and Discussion}

The results of copper adsorption on the various adsorbents were presented in Table 1. After the adsorption process, the adsorbents were added to humus prior to the planting of the garden candytuft. The added adsorbents served as an additional source of copper.

Based on the results shown in Table 1, it can be seen that the highest efficiency of copper adsorption from the aqueous solution of $\mathrm{CuSO}_{4} \cdot 5 \mathrm{H}_{2} \mathrm{O}$ was achieved when egg shells and zeolite NaX were used as adsorbents (98.36\% and $95.22 \%$, respectively). Humus showed lower adsorption efficiency (49.81\%).

The lowest concentration of copper in the seedlings was measured in the control sample $\left(4.31 \mu \mathrm{g} \mathrm{g}^{-1} \mathrm{DW}\right)$ followed by the seedlings that were cultivated in the humus with the addition of zeolite $\mathrm{NaX}\left(27.88 \mu \mathrm{g} \mathrm{g}^{-1} \mathrm{DW}\right.$ ) (Table 2). Although zeolite NaX adsorbed almost all the amount of copper from the solution, it was expected that the garden candytuft cultivated on this soil would uptake a significantly higher copper concentration. However, it turned out that this was not the case. The reason for this lies in the fact that copper ions were adsorbed on zeolite $\mathrm{NaX}$ by ion exchange process [6,29-31] and, hence, the release of copper ions in the ground was weaker, thus, the copper availability was lower. Although the humus adsorption efficiency was $49.81 \%$ the concentration of copper in the seedlings cultivated in the humus with the addition of extra humus on which copper was previously adsorbed was higher $\left(39.82 \mu \mathrm{g} \mathrm{g}^{-1} \mathrm{DW}\right)$ (Table 2$)$ than the one measured in the seedlings that were cultivated in the humus with the addition of $\mathrm{Cu}$-exchanged zeolite $\mathrm{NaX}$. The assumption is that the copper was adsorbed on the surface of the humus by adsorption process, so it was easier for seedlings to adopt these copper ions. The conclusions drawn above were also confirmed by the measured concentrations of copper in the seedlings that were cultivated in a humus with the addition of egg shells, resulting in the highest measured copper level $\left(44.45 \mu \mathrm{g} \mathrm{g}^{-1} \mathrm{DW}\right)$ (Table 2). Although the concentrations of copper in these seedlings are slightly higher than the normal concentration in plant $\left(1-30 \mu \mathrm{g} \mathrm{g}^{-1}\right)$, there are no visible harmful effects on seedlings growth and development, in accordance to the control (Figure 1(a1)-(a3),(a5),(b1)-(b3),(b5),(c1)-(c3),(c5))).
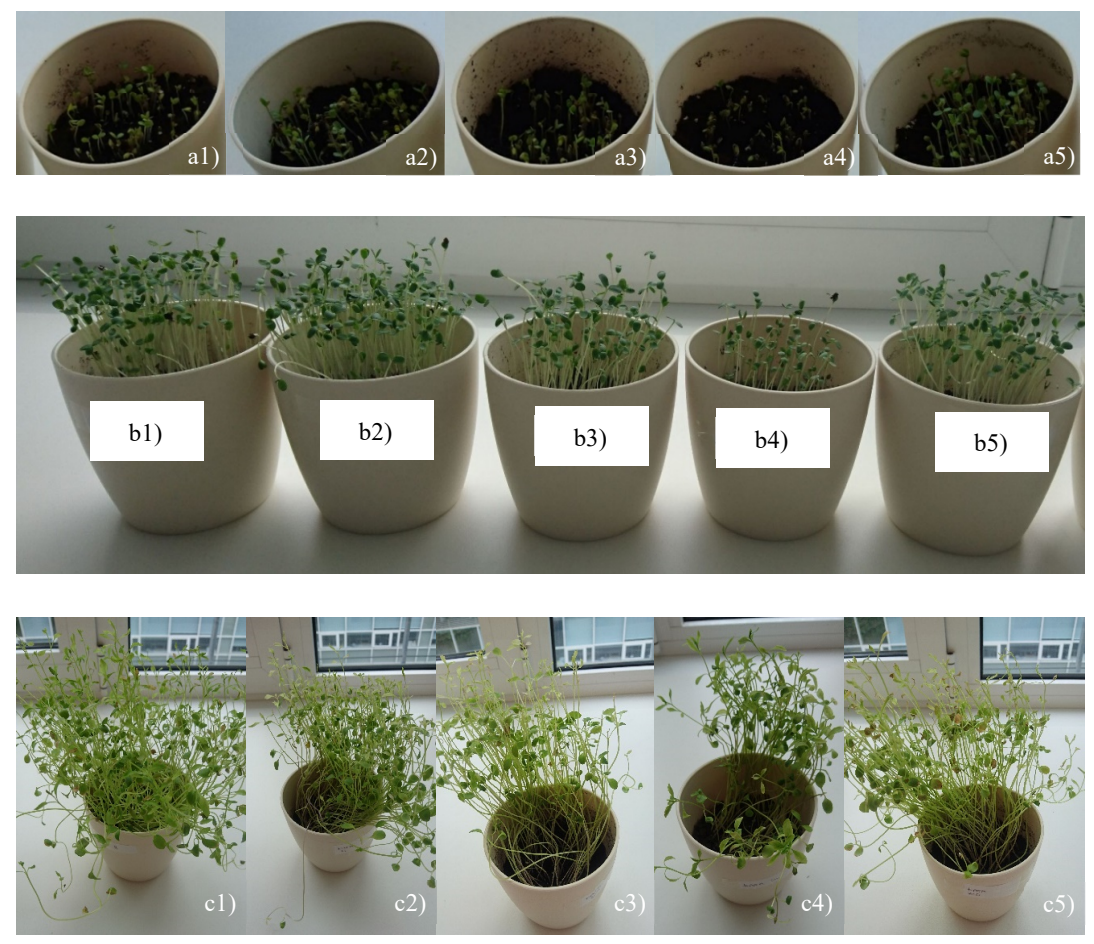

Figure 1. (a) The garden candytuft appearance (a) after five days of cultivation; (b) after ten days of cultivation; (c) after forty days of cultivation: (a1/b1/c1) control sample; (a2/b2/c2) in humus with the addition of egg shells; (a3/b3/c3) in humus with the addition of extra humus; (a4/b4/c4) in untreated humus watered with $\mathrm{CuSO}_{4} \cdot 5 \mathrm{H}_{2} \mathrm{O} ;(\mathbf{a} 5 / \mathbf{b 5} / \mathbf{c 5})$ in humus with the addition of zeolite $\mathrm{NaX}$. 
The highest copper concentration in the garden candytuft was detected when seedlings were watered with a $\mathrm{CuSO}_{4} \cdot 5 \mathrm{H}_{2} \mathrm{O}$ solution $\left(514.63 \mu \mathrm{g} \mathrm{g}^{-1}\right)$. Higher concentration of copper decreased seed germination, as well as the seedlings growth and development (Figure 1(a4),(b4),(c4)). The concentrations of the other elements detected in the garden candytuft were in the normal range [20].

According to the literary data, $\mathrm{Cu}$ hyperaccumulators are plants that accumulate $>1000 \mu \mathrm{g} \mathrm{g}^{-1}$ without showing signs of phytotoxicity and $\mathrm{Cu}$ accumulators are plants that accumulate $>100 \mathrm{\mu g} \mathrm{g}^{-1}$ [20]. Since the garden candytuft watered only with copper solution has stored a high concentration of copper (514.63 $\mu \mathrm{g} \mathrm{g}^{-1} \mathrm{DW}$ ) (Table 2) during the cultivation period, it can be concluded that the garden candytuft is a copper accumulator.

Glucosinolates are characteristic plant metabolites in Brassicaceae family, which act as a defense compounds against patogens and herbivores. Growth and development of plants are influenced by various genetic, environmental, biotic, and abiotic factors, resulting in different glucosinolate content in the obtained plant material [32]. The main glucosinolates identified in the garden candytuft were aliphatic ones that derived from methionine biosynthesis: glucoiberin (1), sinigrin (2), gluconapin (3), glucoibervirin (4), and the minor ones i.e., glucotropaeolin (5) and 4-methoxyglucobrassicin (6), which derived from phenylalanine and tryptophan biosynthesis, respectively. The structures are given in Figure 2.<smiles>[R]/C(=N/OS(=O)(=O)[O-])S[C@@H]1O[C@H](CO)[C@@H](O)[C@H](O)[C@H]1O</smiles>

Thiofunctionalized<smiles>CCCS(C)=O</smiles>

1

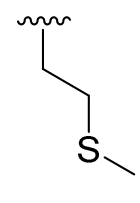

4

$$
\text { Olefinic }
$$<smiles>C=CCCC</smiles>

2

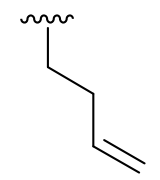

3
Arylaliphatic<smiles>CCc1ccccc1</smiles>

5
Indole<smiles>COc1cccc2[nH]cc(C[Al])c12</smiles>

6

Figure 2. Structures of the glucosinolates identified in the garden candytuft: (1) glucoiberin; (2) sinigrin; (3) gluconapin; (4) glucoibervirin; (5) glucotropaeolin; (6) 4-methoxyglucobrassicin.

The garden candytuft seeds specifically contain high amounts of alipahatic glucosinolates i.e., two followed by one and four. After forty-days of cultivation, these glucosinolates were also the main ones, but with lower amounts in the control sample, having total glucosinolate content of $7852.61 \mu \mathrm{g} \mathrm{g}^{-1} \mathrm{DW}\left(19.38 \mu \mathrm{mol} \mathrm{g}^{-1} \mathrm{DW}\right)$. It was noticed that copper accumulation influences the content of glucosinolates depending on the soil used for cultivation. This was specially observed in the case of the largest content of copper accumulated by plant, where the total glucosinolates content decreased to $3103.33 \mu \mathrm{g} \mathrm{g}^{-1} \mathrm{DW}\left(7.59 \mu \mathrm{mol} \mathrm{g}{ }^{-1} \mathrm{DW}\right)$ (Table 2). It was previously reported that, upon copper exposure, plants produce more amino acids and glucosinolates [33]. In this study, when the copper level was in the normal range or slightly above the total, glucosinolate content increased or did not differ. 


\section{Conclusions}

The garden candytuft showed no differences in seedlings appearance after forty-days of cultivation, regardless of the soil or the watering solutions used. The differences were noticed in the seed germination and the seedling growth rate when pots were watered with $\mathrm{CuSO}_{4} \cdot 5 \mathrm{H}_{2} \mathrm{O}$ solution.

The copper addition was performed indirectly by adding different adsorbents saturated with copper and directly by watering with $\mathrm{CuSO}_{4} \cdot 5 \mathrm{H}_{2} \mathrm{O}$ solution. The results indicate that the garden candytuft uptakes copper from adsorbents in the amount needed for its growth and development with beneficial or no impact on the glucosinolate content. On the contrary, the garden candytuft watered with $\mathrm{CuSO}_{4} \cdot 5 \mathrm{H}_{2} \mathrm{O}$ solution accumulated copper with a sharp decrease in the glucosinolate content. The obtained results indicated that the garden candytuft can be considered as a copper accumulator plant.

These results ensure not only the information of possible copper accumulation ability and the metabolic response on the applied stress, but also the possible disposal of used and saturated adsorbents.

Supplementary Materials: The following are available online at http:/www.mdpi.com/2227-9717/8/ 9/1116/s1, Figure S1: Chromatograms of desulfoglucosinolates obtained from the cultivated garden candytuft: 1-desulfoglucoiberin; 2-desulfosinigrin; 3-desulfogluconapin; 4-desulfoglucoiberverin; 5-desulfoglucotropaeolin; 6-desulfo-4-methoxyglucobrassicin; (A) Seeds of the garden candytuft used for cultivation; (B) The control sample; (C) Seedlings grown in humus with zeolite NaX addition watered only with $\mathrm{H}_{2} \mathrm{O}$; (D) Seedlings grown in humus with extra humus addition watered only with $\mathrm{H}_{2} \mathrm{O}$; (E) Seedlings grown in humus with egg shell addition watered only with $\mathrm{H}_{2} \mathrm{O}$; (F) Seedlings grown in pure humus and watered only with $\mathrm{CuSO}_{4} \cdot 5 \mathrm{H}_{2} \mathrm{O}$; Figure S2: $\mathrm{MS}^{2}$ spectra at $15 \mathrm{~V}$ ionization of desulfoglucosinolates detected. The numbers correspond to the Table 2 and Figure S1.

Author Contributions: M.N.M. conceived and planned the experiments. M.N.M. and S.S. performed experiments dealing with the cultivation of the garden candytuft. M.N.M. and D.O. performed experiments dealing with heavy metals analyses. A.Đ., F.B. and I.B. performed experiments dealing with glucosinolate analyses. M.N.M., S.S. and I.B. drafted the manuscript with the input of all authors. All authors have read and agreed to the published version of the manuscript.

Funding: This research has been fully supported by the Croatian Science Foundation under the projects BioSMe (HRZZ-IP-06-2016-1316; PI IB) and MEBTRACE (HRZZ-IP-09-2014-7530; PI DO). The authors declare that they have no conflict of interest.

Acknowledgments: We are also thankful for the scientific-research equipment financed by EU grant "Functional integration of the University of Split, PMF-ST, PFST and KTFST through the development of the scientific and research infrastructure" (KK.01.1.1.02.0018).

Conflicts of Interest: The authors declare no conflict of interest.

\section{References}

1. Basic, N.; Salamin, N.; Keller, C.; Galland, N.; Besnard, G. Cadmium hyperaccumulation and genetic differentiation of Thlaspi caerulescens populations. Biochem. Syst. Ecol. 2006, 34, 667-677. [CrossRef]

2. Rascio, N.; Navari-Izzo, F. Heavy metal hyperaccumulating plants: How and why do they do it? And what makes them so interesting? Plant Sci. 2011, 180, 169-181. [CrossRef] [PubMed]

3. De Caroli, M.; Furini, A.; DalCorso, G.; Rojas, M.; Di Sansebastiano, G.-P. Endomembrane Reorganization Induced by Heavy Metals. Plants 2020, 9, 482. [CrossRef] [PubMed]

4. Marschner, P. Marschner's Mineral. Nutrition of Higher Plants, 3rd ed.; Elsevier: Amsterdam, The Netherlands, 2012.

5. Malik, A. Metal bioremediation through growing cells. Environ. Int. 2004, 30, 261-278. [CrossRef] [PubMed]

6. Svilović, S.; Rušić, D.; Žanetić, R. Thermodynamics and Adsorption Isotherms of Copper Ions Removal from Solutions Using Synthetic Zeolite X. Chem. Biochem. Eng. Q. 2008, 22, 299-305.

7. Svilović, S.; Rušić, D.; Stipišić, R. Modeling batch kinetics of copper ions sorption using synthetic zeolite NaX. J. Hazard. Mater. 2009, 170, 941-947. [CrossRef]

8. Nibou, D.; Mekatel, H.; Amokrane, S.; Barkat, M.; Trari, M. Adsorption of $\mathrm{Zn}^{2+}$ ions onto NaA and NaX zeolites: Kinetic, equilibrium and thermodynamic studies. J. Hazard. Mater. 2010, 173, 637-646. [CrossRef] 
9. Jovanovic, M.; Grbavcic, Z.; Rajic, N.; Obradovic, B. Removal of $\mathrm{Cu}(\mathrm{II})$ from aqueous solutions by using fluidized zeolite A beads: Hydrodynamic and sorption studies. Chem. Eng. Sci. 2014, 117, 85-92. [CrossRef]

10. Mužek, M.N.; Svilović, S.; Zelić, J. Fly ash-based geopolymeric adsorbent for copper ion removal from wastewater. Desalin. Water Treat. 2014, 52, 2519-2526. [CrossRef]

11. Mužek, M.N.; Svilović, S.; Ugrina, M.; Zelić, J. Removal of copper and cobalt ions by fly ash-based geopolymer from solutions-equilibrium study. Desalin. Water Treat. 2016, 57, 10689-10699. [CrossRef]

12. Mužek, M.N.; Svilović, S.; Zelić, J. Kinetic studies of cobalt ion removal from aqueous solutions using fly ash-based geopolymer and zeolite NaX as sorbents. Sep. Sci. Technol. 2016, 51, 2868-2875. [CrossRef]

13. Pandey, P.K.; Sharma, S.K.; Sambi, S.S. Removal of lead(II) from waste water on zeolite-NaX. J. Environ. Chem. Eng. 2015, 3, 2604-2610. [CrossRef]

14. Yurekli, Y. Removal of heavy metals in wastewater by using zeolite nano-particles impregnated polysulfone membranes. J. Hazard. Mater. 2016, 309, 53-64. [CrossRef] [PubMed]

15. Hong, M.; Yu, L.; Wang, Y.; Zhang, J.; Chen, Z.; Dong, L.; Zan, Q.; Li, R. Heavy metal adsorption with zeolites: The role of hierarchical pore architecture. Chem. Eng. J. 2019, 359, 363-372. [CrossRef]

16. Krämer, U. Metal hyperaccumulation in plants. Annu. Rev. Plant Biol. 2010, 61, 517-534. [CrossRef]

17. Tewes, L.J.; Stolpe, C.; Kerim, A.; Krämer, U.; Müller, C. Metal hyperaccumulation in the Brassicaceae species Arabidopsis halleri reduces camalexin induction after fungal pathogen attack. Environ. Exp. Bot. 2018, 153, 120-126. [CrossRef]

18. Rascio, N. Metal accumulation by some plants growing on zinc-mine deposits. Oikos 1977, 29, $250-253$. [CrossRef]

19. Reeves, R.D. Hyperaccumulation of trace elements by plants. In Phytoremediation of Metal-Contaminated Soils; Morel, J.-L., Echevarria, G., Goncharova, N., Eds.; Springer: Berlin/Heidelberg, Germany, 2006; Volume 68, pp. 25-52.

20. Boyd, R.S. The defense hypothesis of elemental hyperaccumulation: Status, challenges and new directions. Plant Soil 2007, 293, 153-176. [CrossRef]

21. Hunt, A.J.; Anderson, C.W.N.; Bruce, N.; Muñoz García, A.; Graedel, T.E.; Hodson, M.; Meech, J.A.; Nassar, N.T.; Parker, H.L.; Rylott, E.L.; et al. Phytoextraction as a tool for green chemistry. Green Process. Synth. 2014, 3, 3-22. [CrossRef]

22. Mourato, M.P.; Moreira, I.N.; Leitão, I.; Pinto, F.R.; Sales, J.R.; Martins, L.L. Effect of Heavy Metals in Plants of the Genus Brassica. Int. J. Mol. Sci. 2015, 16, 17975-17998. [CrossRef]

23. Blažević, I.; Montaut, S.; Burčul, F.; Olsen, C.E.; Burow, M.; Rollin, P.; Agerbirk, N. Glucosinolate structural diversity, identification, chemical synthesis and metabolism in plants. Phytochemistry 2020, 169, 112100. [CrossRef] [PubMed]

24. Pongrac, P.; Tolrà, R.; Vogel-Mikuš, K.; Poschenrieder, C.; Barceló, J.; Regvar, M. At the Crossroads of Metal Hyperaccumulation and Glucosinolates: Is There Anything Out There? Sherameti, I., Varma, A., Eds.; Springer: Berlin/Heidelberg, Germany, 2010; Volume 19, pp. 139-161.

25. Blažević, I.; Đulović, A.; Čikeš Čulić, V.; Popović, M.; Guillot, X.; Burčul, F.; Rollin, P. Microwave-assisted versus conventional isolation of glucosinolate degradation products from Lunaria annua L. and their cytotoxic activity. Biomolecules 2020, 10, 215. [CrossRef] [PubMed]

26. Brown, P.D.; Tokuhisa, J.G.; Reichelt, M.; Gershenzon, J. Variation of glucosinolate accumulation among different organs and developmental stages of Arabidopsis thaliana. Phytochemistry 2003, 62, 471-481. [CrossRef]

27. Wathelet, J.P.; Iori, R.; Leoni, O.; Quinsac, A.; Palmieri, S. Guidelines for glucosinolate analysis in green tissues used for biofumigation. Agroindustria 2004, 3, 257-266.

28. Šimat, V.; Vlahović, J.; Soldo, B.; Generalić Mekinić, I.; Čagalj, M.; Hamed, I.; Skroza, D. Production and characterization of crude oils from seafood processing by-products. Food Biosci. 2020, 33, 100484. [CrossRef]

29. Svilović, S.; Mužek, M.N.; Nuić, I.; Vučenović, P. Taguchi design of optimum process parameters for sorption of copper ions using different sorbents. Water Sci. Technol. 2019, 80, 98-108. [CrossRef]

30. Yurekli, Y. Determination of adsorption characteristics of synthetic NaX nanoparticles. J. Hazard. Mater. 2019, 378, 120743. [CrossRef]

31. Schenkel, R. Sorption of Small Polar Molecules on Micro- and Mesoporous Zeolitic Materials. Ph.D. Thesis, Fakultät für Chemie, Technische Universität München, München, Germany, 2004. 
32. Jahangir, M.; Abdel-Farid, I.B.; Kim, H.K.; Choi, Y.H.; Verpoorte, R. Healthy and unhealthy plants: The effect of stress on the metabolism of Brassicaceae. Environ. Exp. Bot. 2009, 67, 23-33. [CrossRef]

33. Jahangir, M.; Abdel-Farid, I.B.; Choi, Y.H.; Verpoorte, R. Metal ion-inducing metabolite accumulation in Brassica rapa. J. Plant Physiol. 2008, 165, 1429-1437. [CrossRef]

(C) 2020 by the authors. Licensee MDPI, Basel, Switzerland. This article is an open access article distributed under the terms and conditions of the Creative Commons Attribution (CC BY) license (http://creativecommons.org/licenses/by/4.0/). 